\section{The influence of emotional carrying capacity and network ethnic diversity on entrepreneurial self-efficacy The case of black and white entrepreneurs}

\author{
Golshan Javadian
}

Department of Business Administration, Morgan State University, Baltimore, Maryland, USA

Tina R. Opie

Department of Management, Babson College, Babson Park, Massachusetts, USA, and

Salvatore Parise

Department of Technology, Operations, and Information Management, Babson College, Babson Park, Massachusetts, USA
Case of black and white entrepreneurs

Received 25 August 2018 Revised 14 September 2018 Accepted 17 September 2018

\begin{abstract}
Purpose - One key determinant of entrepreneurial success is entrepreneurial self-efficacy (ESE), defined as an individual's confidence in his or her ability to perform entrepreneurial tasks. Whereas previous research has examined how individual and business factors influence ESE, the purpose of this paper is to analyze the influence of entrepreneurs' social networks upon ESE. The paper examines such relationships for black and white entrepreneurs.

Design/methodology/approach - In total, 110 black and white entrepreneurs responded to a survey measuring ESE and critical constructs representing elements of the quality of entrepreneurs' networks: emotional carrying capacity (ECC) and network ethnic diversity.

Findings - The authors found significant, positive relationships between both ECC and network ethnic diversity on ESE for white entrepreneurs but only found a significant positive relationship between ECC and ESE for black entrepreneurs.

Originality/value - While research is clear about the role that ESE plays in entrepreneurial activities, few studies have focused on the factors that improve ESE. In the present work, the authors study the role of context by examining how entrepreneurs' social networks influence ESE. The authors examine such influences for both white and black entrepreneurs to better understand the implications of ethnicity.
\end{abstract}

Keywords Entrepreneurial self-efficacy, Emotional carrying capacity, High-quality connections,

Network ethnic diversity

Paper type Research paper

\section{Introduction}

Entrepreneurship, known as the creation of new ventures (Bruyat and Julien, 2000), is a popular and important pursuit, but it is not without challenges. According to a US Small Business Administration (2012) report, about two-thirds of businesses survive at least two years and about

(C) Golshan Javadian, Tina R. Opie and Salvatore Parise. Published in New England Journal of Entrepreneurship. Published by Emerald Publishing Limited. This article is published under the Creative Commons Attribution (CC BY 4.0) licence. Anyone may reproduce, distribute, translate and create derivative works of this article (for both commercial and non-commercial purposes), subject to full attribution to the original publication and authors. The full terms of this licence may be seen at http://creativecommons.org/licences/by/4.0/legalcode

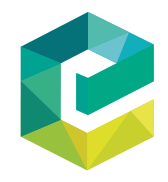

New England Journal of Entrepreneurship Entrepreneurship
Vol. 21 No. 2, 2018 pp. $101-122$ Emerald Publishing Limited DOI 10.1108/NEJE-08-2018-0016 
NEJE

21,2

102

half of businesses survive at least five years. Relatedly, Brownlee (2014) reports that roughly 80 percent of startups fail for a variety of reasons, with incompetence (e.g. no knowledge of industry pricing conventions, no experience in record-keeping) and lack of managerial experience (e.g. poor credit-granting decisions) accounting for 76 percent of small business failures.

In general, business failure rates are higher for minority-owned businesses (Bates et al., 2007), with businesses owned by black and Hispanic entrepreneurs failing at greater rates than those owned by white entrepreneurs (Koellinger and Minniti, 2006; Meyer, 1990; Robb, 2002). Similarly, businesses owned by women have higher failure rates than those owned by men (Robb, 2002). This backdrop suggests that during the start of a new venture, entrepreneurs, and especially minority entrepreneurs, may benefit from considering how they might increase their likelihood of entrepreneurial success. An important part of this consideration is individuals' entrepreneurial self-efficacy (ESE). ESE, defined as an individual's confidence in his or her ability to perform entrepreneurial tasks and roles successfully (Chen et al., 1998), is a key determinant of entrepreneurial success (Baum and Locke, 2004; Boyd and Vozikis, 1994; Zhao et al., 2005). The specificity of the ESE concept is helpful because efficacy beliefs are not global in nature but a varying belief system connected to specific domains (Bandura, 2006).

ESE is known to have important implications for entrepreneurial activities. Individuals with higher ESE are more likely to form entrepreneurial intentions (Boyd and Vozikis, 1994; Krueger, 1993), start a business (Markman et al., 2002; Zhao et al., 2005), and successfully grow their business (Baum et al., 2001; Baum and Locke, 2004; Forbes, 2005; Hmieleski and Baron, 2008). ESE is also important because it mediates the effects of individual-level factors such as perceived learning (i.e. from entrepreneurship-related courses), previous entrepreneurial experience, and risk propensity on entrepreneurial intentions (Zhao et al., 2005). Additionally, for entrepreneurs who have high levels of self-efficacy, improvisational behavior has a positive impact upon new venture performance (Hmieleski and Corbett, 2008). Additionally, higher levels of self-efficacy lead to a higher engagement in high-growth ventures among women entrepreneurs (Muntean and Ozkazanc-Pan, 2015; Sweida and Reichard, 2013). Overall, ESE is positively associated with a host of positive entrepreneurial outcomes for entrepreneurs.

While research is clear about the role that ESE plays in entrepreneurial activities, few studies have focused on factors that improve ESE. Among these few studies, Cox et al. (2002) found that entrepreneurship education positively influenced ESE. Additionally, Forbes (2005) found that strategic decision-making processes within a venture influence the entrepreneur's ESE. For minority entrepreneurs such as women entrepreneurs, educational programs and governmental policies improve ESE (Muntean and Ozkazanc-Pan, 2015). While this research illuminates the influence of individual-level factors upon ESE, we argue that context also matters.

In the present work, we study the role of context by examining how entrepreneurs' social networks influence ESE. We examine such influences for both white and black entrepreneurs to better understand the implications of ethnicity. Among all ethnic categories, we decided to compare black and white entrepreneurs given the history of racial discrimination against black entrepreneurs. Comparing black and white entrepreneurs in terms of the influence of their networks upon ESE enables us to better understand how these two groups may similarly or differently use their entrepreneurial networks to navigate the entrepreneurial landscape.

Entrepreneurs' social networks, which include family, organizational, and community-based ties, are known to supplement the effects of the entrepreneurs' experience, education, and financial resources (Coleman, 1990). Social networks influence outcomes based on the pattern of direct and indirect ties between network actors (Burt, 1995; Hoang and Antoncic, 2003). Additionally, network composition is of importance for employee and business performance (Ibarra, 1995; Klyver and Terjesen, 2007; Renzulli et al., 2000; Thomas, 1990, 1993). While a traditional view of the benefit of one's social network focuses upon access to resources such as financial, physical, intellectual, and social capital, this perspective portrays the owner or entrepreneur narrowly as a manager of resources. However, effective entrepreneurs also take a relational view and think of 
their personal network as providing critical connections to opportunities (Aldrich et al., 1986). With this view in mind, herein we examine how ESE is influenced by two contextual factors that relate to critical connections, namely the quality of connections and the ethnic diversity of entrepreneurs' social networks. These two factors are indicators of social network composition and governance mechanisms. High quality of connections between network actors has been associated with higher quality of resource flows, and one element of connection quality is the emotional carrying capacity (ECC). ECC is defined as relationship partners' mutual abilities to express more of their positive and negative emotions in a constructive way (Stephens et al., 2013). The ethnic diversity of an entrepreneur's social network refers to the coexistence of diverse ethnicities in that network. We expect these two factors to influence ESE.

High-quality connections are formed based on relationship quality, which is an individual-level factor, and relationship context, which is an environmental-level factor (Settoon and Mossholder, 2002). The ethnic diversity of entrepreneurs' social networks is also influenced by individual characteristics and the environmental context. For example, entrepreneurs' demographics (e.g. ethnicity), personal characteristics (e.g. friendliness and non-discrimination), and environment (e.g. living in an ethnic minority enclave) influence the ethnic diversity of their social networks (Singh, 2000). Moreover, research (e.g. Singh, 2000) has shown that both individual and environmental aspects of social networks are crucial to entrepreneurial activities such as opportunity recognition. However, such influence has not been examined for ESE. In other words, we do not know the extent to which these two specific features of social networks may influence the ESE of black and white entrepreneurs.

High-quality connections offer psychological safety to individuals (Kahn, 1990). Moreover, knowledge is transferred more effectively through high-quality connections (Dutton and Heaphy, 2003; Wenger, 2000). Accordingly, it can be argued that high-quality connections between the entrepreneur and their network actors can improve ESE as a result of enhanced psychological safety and improved knowledge. Also, as Dutton and Heaphy (2003) argue, high-quality connections, and specifically high-ECC connections, help individuals value their identity and grow. Similarly, it can be argued that entrepreneurs who have high-quality connections with people in their network will value their entrepreneurial identity more, and as a result, their ESE will improve. We also argue that both black and white entrepreneurs can benefit from ethnically diverse networks. We believe that such networks allow entrepreneurs to access novel and non-redundant information, information that can improve ESE. Figure 1 illustrates the conceptual model of our study.

The rest of this paper is organized as follows. We first discuss social network theory and its implications for entrepreneurial activities. Then, using this theory, we argue how ECC

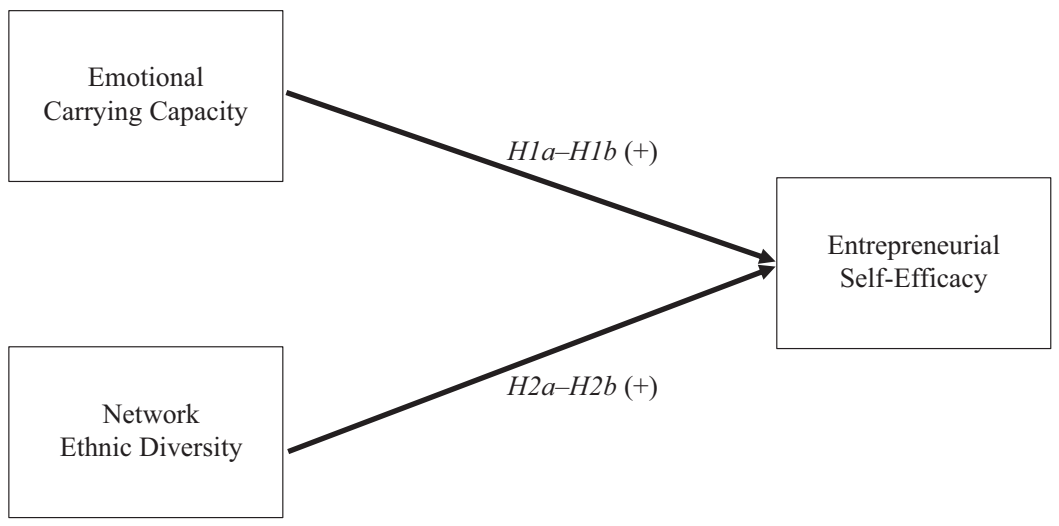

Case of black and white entrepreneurs
Figure 1. Hypothesized impacts of emotional carrying capacity and network ethnic diversity upon

ESE of black and white entrepreneurs 
NEJE

21,2

and network ethnic diversity likely impact the ESE of both black and white entrepreneurs. Specifically, we assert that ECC improves the ESE of black and white entrepreneurs by creating secure relationships for entrepreneurs. Also, we assert that high-ECC helps entrepreneurs better attend to their social environment and represents networks characterized by positive emotion. Further, we posit that network ethnic diversity is positively related to the ESE of both black and white entrepreneurs because as network ethnic diversity increases, entrepreneurs have access to more novel information and more accurate opportunity assessment.

\section{Theory and hypothesis development}

\section{Social network theory}

According to social network theory (Burt, 2004), belonging to a social network offers individuals the advantage of social capital. Entrepreneurs are embedded in social networks and networks play a critical role in entrepreneurial success (Aldrich et al., 1986). They increase entrepreneurs' access to information and knowledge by expanding their bounded rationality (Singh, 2000). In other words, social networks help entrepreneurs overcome their limited ability to access and process information by providing them with knowledge they could have not obtained on their own. Social networks work as media through which entrepreneurs gain access to a variety of resources (Hoang and Antoncic, 2003; Zimmer and Aldrich, 1987), identify business ideas and opportunities (Singh, 2000), and start and run successful ventures (Honig and Davidsson, 2000; Renzulli and Aldrich, 2005; Robinson and Stubberud, 2010). Specifically, social networks help entrepreneurs gain access to capital, including financial capital (Granovetter, 1985; Greve and Salaff, 2003; Zimmer and Aldrich, 1987). Also, social networks influence the entrepreneurs themselves by providing them with the emotional support they need for entrepreneurial risk-taking (Brüderl and Preisendörfer, 1998; Renzulli and Aldrich, 2005).

Social networks have been researched from different perspectives including the perspective of network governance mechanisms and network composition. The term governance mechanism refers to a mechanism that coordinate network exchange (Hoang and Antoncic, 2003). Within the governance perspective, the quality of the relationship between entrepreneurs and their social networks has received little attention, and research in this area has been limited mostly to trust between network actors. Trust has been shown to enhance the quality of resource flows (Larson, 1992), enrich the quality of information exchanged (Lorenzoni and Lipparini, 1999), and reduce transaction costs (Jones and Seguin, 1997). ECC is another important aspect of high-quality relationships (Dutton and Heaphy, 2003) that has not been examined in entrepreneurial social network research.

Social networks have also been examined from the viewpoint of network composition (Klyver and Terjesen, 2007; Renzulli et al., 2000). Research found that gender heterogeneity in networks represents a critical advantage for entrepreneurs (Renzulli et al., 2000). Forming network ties with dissimilar others is argued to benefit entrepreneurs by expanding their knowledge through indirect ties to others beyond their immediate circle and by compensating for their biased perceptions about venture start-up (Renzulli et al., 2000). Given the benefits of network heterogeneity, it is surprising that the aspect of ethnic diversity remains unexplored within study on network composition.

\section{Black vs white entrepreneurship}

Several differences have been found in the ventures created by black and white entrepreneurs. Compared to white entrepreneurs, black entrepreneurs open smaller ventures that generate little or no economic gain (Fairlie and Robb, 2008), have lower employment rates (Fairlie and Robb, 2007), and experience higher rates of venture failure (Fairlie and Robb, 2008; 
Robb, 2002). Such differences have been attributed to differences in access to resources, and research has found that racial discrimination at least partially explains why black entrepreneurs have less access to resources (Blanchflower et al., 1998; Fairlie and Robb, 2007). For example, compared to their white counterparts, black entrepreneurs receive less frequent approval for credit and when they are approved are charged higher interest rates (Blanchflower et al., 1998); have fewer opportunities than white entrepreneurs to acquire valuable work experience before starting a business (Fairlie and Robb, 2008); receive less venture capital funding (Fairlie and Robb, 2007); and have less access to formal and informal network contacts to provide them with information and resources (Singh et al., 2008).

Yet, despite racial discrimination, black entrepreneurs are making significant entrepreneurial strides. Based on a 2012 survey of business owners, the number of black-owned firms has increased 34 percent since 2007. Interestingly, black women-owned businesses grew 66.9 percent during this period, making black women the fastest growing group of entrepreneurs in the USA. Overall, black entrepreneurs are creating ventures at a higher rate than their white or other-minority counterparts (Kelley et al., 2015). Thus, black entrepreneurs as a whole are overcoming racial barriers and flourishing despite racial discrimination. It is possible that marginalized members of society, such as black entrepreneurs, may develop assets or resources because of their collective's unique experience with oppression (DuBois, 1903). While this assertion may be new to entrepreneurship research, literature in fields as diverse as history, philosophy, and positive organizational psychology provide theoretical support for this assertion (Fulbright, 1985; Merolla, 2013). Because of the collective experience of racial oppression, black entrepreneurs may be likely to develop higher levels of ESE than their white counterparts through the resilience they have developed in response to their disadvantaged position. While this is perhaps a surprising argument, ethnicity has already been found to be an important factor shaping self-efficacy. For example, research has shown that ethnic variables (e.g. ethnic identity, other-group orientation) are important predictors of career decision-making self-efficacy for racial and ethnic minorities (Gloria and Hird, 1999). Thus, it is important to examine black entrepreneurs' ESE with comparison to white entrepreneurs to see if similar contextual factors influence their ESE. Below we examine the impact of ECC and network ethnic diversity upon black and white entrepreneurs' ESE. We believe that our approach is helpful not only because it includes an examination of social networks based on previously unexplored features, but also because it highlights the impact of social networks upon ESE for both groups.

\section{Quality of network connections: the role of emotional carrying capacity}

The quality of the connection between network actors has been found to enhance the quality of resource flows (Dutton and Heaphy, 2003; Larson, 1992; Lawler and Yoon, 1998), enrich the quality of information exchanged (Hite, 2005; Lorenzoni and Lipparini, 1999), and reduce transaction costs (Jones et al., 1997). In this section, we examine how one element of connection quality, the ECC of entrepreneurs' social networks, relates to ESE. ECC is defined as relationship partners' mutual abilities to express more of their positive and negative emotions in a constructive way (Stephens et al., 2013). ECC has been studied in the organizational context and has been found to be a source of individual and team resilience (Stephens et al., 2013). In the workplace, ECC is related to psychological safety and improved learning (Carmeli et al., 2009). We posit that ECC provides similar benefits in the entrepreneurial context. Emotional connections with network ties can improve entrepreneurs' abilities to face difficulties and enhance entrepreneurs' learning. In addition, ECC may improve the flow of resource exchange and also contribute to the creation of new and valued resources (Dutton and Heaphy, 2003).

ECC can be especially important for black entrepreneurs in improving their ESE. Research has found that black entrepreneurs have less self-confidence and more fear of 
NEJE

21,2

failure compared to white entrepreneurs (Preisendörfer et al., 2012). Research has previously shown that black entrepreneurs specifically are motivated by their role models and their emotional connections with them (Edelman et al., 2010). Accordingly, the ECC between black entrepreneurs and their role models or other social network actors may be an important contributor to improving ESE. Despite the potential importance of ECC as an important contextual factor for entrepreneurs and especially for black entrepreneurs, ECC has been largely ignored in the entrepreneurship literature.

In the following section we argue that the ECC of an entrepreneur's social network connections will be positively related to his or her ESE. Our argument is based upon three premises: ECC influences ESE by creating secure relationships that provide entrepreneurs the space to receive encouragement and constructive criticism and to engage in self-reflection; entrepreneurs with high-ECC connections will better attend to their social environment because of helpful cues and benchmarking provided by their network partners; and high-ECC connections are characterized by positive emotion. We contend that secure connections that facilitate self-reflection, attention to the social environment, and positive emotions provide entrepreneurs safe space to soberly reflect on themselves and their social environment, thereby enhancing ESE. ESE improves with positive encouragement and feedback from others (Wilson et al., 2007). As a contextual factor, ECC contributes to ESE by providing both black and white entrepreneurs a relationship through which the entrepreneur learns but also receives emotional support. Below is a detailed discussion of these notions.

High-ECC connections, relational security, and self-reflection. ECC creates secure, safe relational spaces (Dutton and Heaphy, 2003; Stephens et al., 2013) that provide relationship partners with greater freedom of expression, more learning, greater risk taking, and greater ability to share ideas (Edmondson, 1999; Stephens et al., 2013). We posit that the security provided by high-ECC connections provides entrepreneurs the opportunity to receive and learn from others via encouragement as well as constructive criticism about their entrepreneurial ideas. Learning from encouragement and constructive criticism is indicative of verbal persuasion (e.g. feedback that you or your idea is good; Bandura, 1977; Chen et al., 1998). Verbal persuasion is a key source of self-efficacy, along with enactive mastery (i.e. feedback on performance and personal experience), vicarious experience (e.g. learning through role models), and physiological/affective arousal (Bandura, 1997). Accordingly, we argue that ECC improves ESE through verbal persuasion.

Further, individuals in secure relationships are more likely to develop a learning and mastery orientation (Sutcliffe and Vogus, 2003) and to gain access to resources (Stephens et al., 2013). Finally, we argue that the security provided by high-ECC connections provides entrepreneurs a safe opportunity to self-reflect, whereby they can consider entrepreneurial tasks at hand, think about how their prior experiences may generalize in the current situation, and reframe negative feedback in an adaptive manner (Tams, 2007). Such self-reflection is indicative of enactive mastery, a key source of self-efficacy (Bandura, 1997). Self-reflection is particularly relevant for entrepreneurs because entrepreneurial activity may be isolating at times, requiring individuals to believe in their ability to accomplish their tasks and pursue their goals even if no one else believes in their ideas or intervenes on their behalf (Markman and Baron, 2003; Sarason et al., 2006).

Thus, the security provided by high-ECC connections should support entrepreneurs in adopting a learning and mastery orientation, and provide them with the opportunity for verbal persuasion and enactive mastery, all of which are key levers to increase self-efficacy (Bandura, 1977) and, we argue, to increase ESE. This assumption is true for both black and white entrepreneurs. Both groups benefit from the security provided by their high-ECC connections and their ESE is expected to improve as the result of the increased verbal persuasion and enactive mastery imparted by high-ECC connections. 
High-ECC connections and the social environment. In addition to engaging in self-reflection, entrepreneurs must also attend to their social environment, taking cues to develop and refine their entrepreneurial pursuits (Meek et al., 2010; Tams, 2007). In high-ECC relationships, entrepreneurs can attend to their social environment by responding to friendly verbal and non-verbal cues from network partners that signal idea feasibility, social support, etc. (Tams, 2007). These cues, embedded in constructive interactions and linked to verbal persuasion, help to build self-efficacy.

In high-ECC relationships, entrepreneurs may be able to benchmark by using their network partners' experiences as helpful models for future plans (Tams, 2007). For example, consider the case of an entrepreneur considering the timing of a new market entry, and receiving constructive criticism from a network partner for whom slowing market entry led to a better outcome. If the relationship between these two people is of high ECC, the entrepreneur may be more likely to benefit from this interaction, and may decide to refine how quickly they enter the new market. We posit that if the entrepreneur received the same criticism from a network partner with whom they did not share a high-ECC relationship, the input might be dismissed or discounted. We hold this assumption regarding both black and white entrepreneurs. Thus, we assert that both black and white entrepreneurs in high-ECC relationships will have higher ESE because they will better attend to their social environment via cues and benchmarking from their network partners.

High-ECC connections and positive emotions. High-ECC connections also provide relationship partners with more positive emotions than individuals in low-ECC relationships (Dutton and Heaphy, 2003). Specifically, as compared to low-ECC connections, high-ECC connections are characterized by more vitality, personal regard (i.e. the sense that one is known and understood), and mutual understanding (i.e. feeling an active connection) between relationship partners (Dutton and Heaphy, 2003). Given the positive relationships between positive emotions and self-efficacy (Kirschenbaum et al., 1985) and positive emotions and improved cognition and motivation in task performance (Tams, 2007), we argue that the positive emotions characteristic of high-ECC connections will contribute to higher ESE.

Overall, we assert that entrepreneurs having social network connections characterized by high ECC will have higher relational security, be more self-reflective, be more attentive to their social environment, and experience more positive emotions. These factors should enhance the ESE of any entrepreneur, including white and black entrepreneurs. As previously noted, research suggests that black entrepreneurs have less access to resources. ECC can, to some extent, make up for such lack of resources. ECC helps black entrepreneurs to be more attentive to their social environment, which may help them identify resources not otherwise visible to them. The relational security and self-reflection afforded by high-ECC relationships can also help black entrepreneurs search for resources more actively. The resulting increased access to resources combined with positive emotions can indeed improve the ESE of black entrepreneurs. Therefore, we make the following two hypotheses:

H1a. The ECC of a white entrepreneur's social network connections is positively related to his or her ESE.

H1b. The ECC of a black entrepreneur's social network connections is positively related to his or her ESE.

\section{Entrepreneurs' network ethnic diversity: benefit of heterogeneous networks}

We argue that, like the ECC of entrepreneurs' network connections, the ethnic diversity of entrepreneurs' networks is an understudied contextual factor that influences ESE. We assert that network ethnic diversity benefits both black and white entrepreneurs by countering the effects of racially segregated networks and providing access to more novel information and
Case of black and white entrepreneurs 
NEJE

21,2

more accurate opportunity assessment. Our argument is based upon three premises: heterogeneous networks yield more novel information and more accurate opportunity assessment; social networks are often highly racially segregated, but network ethnic diversity benefits both underrepresented and white entrepreneurs; and network ethnic diversity is related to access to novel information and more accurate opportunity assessment. Below is a detailed discussion of these three premises.

Heterogeneous networks and novel information. Social networks are an important source of information for entrepreneurs (Baron et al., 2005), and novel information received from social networks contributes to entrepreneurial activities (Davidsson and Honig, 2003). Research has found that heterogeneity, one of the most direct indicators of social network diversity, is a critical advantage for entrepreneurs (Renzulli et al., 2000). Higher network diversity provides individuals entrée to different societal spheres, enabling them to access novel information (Blau, 1977; Blau and Alba, 1982; Brass, 1984; Ibarra, 1995). Forming network ties with dissimilar others has been found to benefit entrepreneurs by expanding their knowledge through indirect ties to others beyond their immediate circle and by compensating for their biased perceptions about venture start-up (Renzulli et al., 2000).

Reagans and Zuckerman (2001) found that network heterogeneity was significantly predictive of team productivity. Specifically, connections with diverse others provided access to different, information, perspectives, and sets of experiences, which enhanced learning and productivity. That is, heterogeneous networks helped to span structural holes that reflected divisions in the larger social system (Reagans and Zuckerman, 2001). Those with networks that span boundaries between groups tend to have greater access to non-redundant information (Burt, 1982, 1995). In contrast, more homogenous networks fail to span structural holes and tend to have more redundant information (Burt, 1995) because these networks rely on information contained within the homogenous group. Overall, as compared to homogeneous networks, heterogeneous networks provide network members with more novel information, and this is relevant for both black and white entrepreneurs. Additionally, those in heterogeneous networks may make better decisions, as they process information more deeply and make more accurate decisions when assessing opportunities (Apfelbaum et al., 2014).

Highly racially segregated networks vs ethnically diverse networks. In the USA, social networks are highly segregated by race; in fact, race and ethnicity are considered to be the biggest divide in US social networks (McPherson et al., 2001). These highly racially segregated networks occur for two main reasons: in the USA, homophily within opportunity structures (US population, workplace interactions, etc.) means that white Americans have more racially homogenous networks than other ethnic groups; and individuals may choose to identify with racially similar others (McPherson et al., 2001). Given the benefits of heterogeneous networks, we argue that racially segregated networks deprive entrepreneurs of novel information contained in the networks of ethnically dissimilar entrepreneurs.

Social network research posits that underrepresented minorities such as black entrepreneurs benefit from network relationships with white individuals because whites have greater social capital and access to experts (Cummings, 1999; Falemo, 1989). However, we argue that white entrepreneurs may also benefit from access to underrepresented ethnic minorities for two key reasons. First, although minorities may have less network access to experts (Cornwell and Cornwell, 2008), ethnic minorities may be just as or more creative than their white network members (Duguid and Goncalo, 2015). Creativity is positively associated with entrepreneurship (Lee et al., 2004; Shalley and Perry-Smith, 2008), and individual creativity is positively related to entrepreneurial opportunity recognition (Ardichvili et al., 2003; Dimov, 2007; Kirzner, 2009), business idea development (Puhakka, 2007), and entrepreneurial intentions (Yar Hamidi et al., 2008). Thus, we argue that access to ethnic minorities may enhance creativity and positively influence entrepreneurial outcomes. 
Second, racial discrimination and social exclusion may prevent ethnic minorities from fully engaging in the mainstream economy; thus, these individuals may create ventures that meet needs previously unaddressed by the mainstream (Valdez, 2011). Access to such ventures may provide novel information and business opportunities that have not yet reached the largely white mainstream economy. Hence, white entrepreneurs whose networks include ethnic minorities may be able to tap into opportunities that are less perceptible to White entrepreneurs whose networks are more homogeneous.

Network ethnic diversity and accurate opportunity assessment. Given that network heterogeneity is associated with novel information, we argue that network ethnic diversity, a type of network heterogeneity, is also positively associated with novel information and its associated benefits. We contend that both black and white entrepreneurs whose networks are ethnically diverse will benefit from the novel information held by members of previously undertapped communities and that the non-redundant information will likely boost an individual's ESE (Ozgen and Baron, 2007). These arguments rest on social network theory, which finds that network heterogeneity positively influences access to non-redundant information. Similarly, as network ethnic diversity increases, entrepreneurs will have greater access to non-redundant information and deeper cognition, leading to more accurate opportunity assessment (Apfelbaum et al., 2014). We argue that as entrepreneurs obtain more non-redundant information and engage in more accurate opportunity assessment, they will become more confident in their ability to perform entrepreneurial tasks and roles successfully, and that this holds true for both black and white entrepreneurs. Therefore, we make the following two hypotheses:

H2a. The network ethnic diversity of a white entrepreneur's social network relationships is positively related to his or her ESE.

$H 2 b$. The network ethnic diversity of a black entrepreneur's social network relationships is positively related to his or her ESE.

\section{Method}

In our study, we pursued initial evidence that ESE would be positively related to participation in social networks of higher network ethnic diversity and higher ECC. We anticipated that these ESE relationships would apply for both white and black entrepreneurs regardless of the entrepreneurs' other demographics and business characteristics (e.g. gender, age, education level, company sales, and company size).

\section{Research setting and data collection}

A web-based, cross-sectional, anonymous survey was developed and distributed to a random sample of US entrepreneurs. We collected data from the panel provider Qualtrics, who sent an online survey link to individuals each of whom had started and run their own business in the USA. Since we were interested in understanding the proposed relationships for black and white entrepreneurs, we collected survey responses for each of these two dimensions. Our goal was to obtain a minimum of 50 responses for each of the two categories based on our power and sample size calculations (Lenth, 2006).

The questionnaire was sent via Qualtrics to a Qualtrics panel of 2,802 qualified individuals. We instructed Qualtrics to collect 20-25 participants in each of four conditions: black male entrepreneurs, black female entrepreneurs, white male entrepreneurs, and white female entrepreneurs. We provided these specific instructions because of the cost-prohibitive nature of collecting data from panel providers. Further, given our continuing interest in collecting entrepreneurial data, we did not want to contaminate the data source by exposing all panel participants to the current study. Importantly, we used 
NEJE

21,2

110

Qualtrics because the firm vets panel participants to ensure that they are actual entrepreneurs. This increases the likelihood that our results are generalizable to other entrepreneurs. We received a total of 112 completed surveys from business owners. We excluded two responses from our sample because they were outliers in terms of company sales and size, thus leaving sample size of 110 . Two test questions were placed in the middle of the survey to ensure respondents were attentive when answering questions ("To make sure the respondents are paying attention to the content of this survey, we ask you to pick the opposite of the word 'Good'." and "To make sure the respondents are paying attention to the content of this survey, we ask you to pick a synonym for the word 'Beautiful'."); all 110 respondents selected the correct answers to these questions ("Bad" and "Pretty", respectively). We used the GPower program to test for the minimum required sample for a hierarchical regression $/ R^{2}$ change test to achieve adequate power, based on the number of tested predictors (i.e. our network variables) and total predictor variables. Our sample size of 110 was determined to exceed the minimum requirement.

Tables I-III summarize respondents' profile information in the categories of demographics, industry, and state location.

\section{Variable measures}

We studied entrepreneurs' networks using the name generator methodology (Wasserman and Faust, 1994). The name generator approach has been a standard method for analyzing personal networks (i.e. ego networks; Burt, 1995, 1998), including entrepreneurs' networks (Aldrich, 1989; Greve and Salaff, 2003; Singh, 2000). Typically, each research participant is presented with one or more questions that elicit a list of names (i.e. alters) of people in the participant's network. The size of the name list requested varies depending on the nature of the study but is usually five at a minimum (see, e.g. Renzulli et al., 2000; Díaz García and Carter, 2009). The researcher can then analyze the network based on its structure

\begin{tabular}{lccc}
\hline Demographics & Number of respondents & Mean & SD \\
\hline Ethnicity & & & \\
Black & 54 & - & - \\
White & 56 & - & \\
Gender & & & - \\
Male & 54 & - & - \\
Female & 56 & 49.03 & 13.18 \\
Age & 110 & 4.25 & 1.47 \\
Education level & 110 & &
\end{tabular}

Industry

Professional, scientific, or technical services

Retail trade

Other services (except public administration)

Construction

Arts, entertainment, or recreation

Table II.

Respondents' industries

Finance or insurance

Real estate or rental and leasing
Number of respondents

Note: Only industries with more than three responses are listed 


\begin{tabular}{|c|c|c|}
\hline State & Number of respondents & $\begin{array}{l}\text { Case of black } \\
\text { and white }\end{array}$ \\
\hline California & 14 & entrepreneurs \\
\hline Ohio & 9 & \\
\hline Georgia & 7 & \\
\hline Florida & 6 & \\
\hline Virginia & 6 & \\
\hline Massachusetts & 5 & 111 \\
\hline Michigan & 5 & \\
\hline New York & 5 & \\
\hline Colorado & 4 & \\
\hline Illinois & 4 & \\
\hline South Carolina & 4 & Respondents \\
\hline Note: Only states with more than three responses are listed & & across states \\
\hline
\end{tabular}

(e.g. structural holes, density), type (e.g. informational ties, emotional ties, friends, professionals), and nature of relationships (e.g. strong or weak ties, diversity).

We used the following name generator question to record a five-person network for each entrepreneur: "Please list the names of five (5) people with whom you most regularly discuss business matters and respond to the following questions about each contact." Each respondent provided five names. We then asked the participants to identify the ethnicity of the contact and to respond to questions related to ECC between the entrepreneur and the contact person.

Emotional carrying capacity. The ECC of the entrepreneurs' network was calculated using three items related to ECC for each contact in their network (Stephens et al., 2013). A five-point Likert scale was used for each item (ranging from 1 for "strongly disagree" to 5 for "strongly agree"). Sample items included "I can fully express my emotions to this person" and "When we interact with each other, we express both positive and negative feelings to each other." The average (across the five-person network) Cronbach's $\alpha$ score for ECC was 0.89. Factor analysis yielded one component consisting of all three items explaining, on average, 83 percent of the variance. The lowest component loading for any item was 0.80 . The mean score for ECC across each entrepreneur's five-person network was 4.07.

Network ethnic diversity. Entrepreneur respondents identified the ethnicity of each contact in their network by selecting one of the following responses: "White/Caucasian", "African American", "Hispanic", "Asian”, "Native American", "Pacific Islander", and "Other." Roughly 90 percent of the network across the entire sample was of either white/Caucasian or African American, with the remaining 10 percent distributed across the other ethnic groups.

To measure the diversity of a group with regard to a nominal feature such as ethnicity or gender, researchers generally employ the Blau index of heterogeneity (Baum et al., 2000; Blau, 1977). The Blau index is calculated using the formula $1-\sum p_{i}^{2}$, where $p$ is the proportion of group members in a given category and $i$ is the number of different categories of the feature across all groups. Higher Blau index scores indicate a greater diversity in the network. For example, an entrepreneur who has four white/Caucasian network contacts and one African American network contact has a Blau index score of $1-\left((0.8)^{2}+(0.2)^{2}\right)=0.32$.

Ethnic diversity network scores ranged from 0 to 0.80 across the sample of 110 respondents, with a mean of 0.24 . Several of the respondents had a completely homogeneous ethnic network (i.e. all network members were of one ethnic group), corresponding to the minimum Blau index of 0 , thus producing the low overall mean network ethnic diversity.

Entrepreneurial self-efficacy. ESE was measured using a six-item scale reflecting the entrepreneur's general belief in his or her capabilities to grow his or her business (DeNoble et al., 1999). A five-point Likert scale was used for each item (ranging from 1 for "strongly disagree" to 5 for "strongly agree"). Sample items included "I can work 
NEJE

21,2

productively under continuous stress, pressure, and conflict" and "I can originate new ideas and products." ESE has been assessed using a general self-efficacy measure (e.g. Markman et al., 2005), which assesses multiple specific dimensions of entrepreneurship (DeNoble et al., 1999), or more recently using a measure that assesses the general entrepreneurial task domain (Baum and Bird, 2010; Bullough et al., 2014; Cassar and Friedman, 2009; Dimov, 2010; Hopp and Stephan, 2012; Murnieks et al., 2014; Zhao et al., 2005). Given our theoretical interest in entrepreneurs' overall ESE and considering time limitations on our study, we utilized a measure of self-efficacy for the general entrepreneurial task domain.

Reliability testing was carried out using Cronbach's $\alpha$ measures, whereas factor analysis was conducted using principal components extraction (eigenvalues $>1$ ). The Cronbach's $\alpha$ score for ESE was 0.83. Factor analysis yielded one component consisting of all six items, explaining 54 percent of the variance. The lowest component loading for any item was 0.62 . The mean score for ESE was 4.22.

Entrepreneur's ethnicity. Our sample consisted of 56 white and 54 black entrepreneurs. White entrepreneurs were coded as 0 , and black entrepreneurs were coded as 1 .

\section{Control variables}

We included several control variables because previous research has shown that certain entrepreneurs' demographics and the characteristics of their business and industry may have an impact upon their self-efficacy and the types of personal networks that they form.

Entrepreneur's gender. Previous research indicates there are gender-specific barriers to entrepreneurial success and the general process of new business development (Murphy et al., 2007). Further, gender influences the types of ties in the entrepreneur's network (Kwon and Arenius, 2010). For example, women entrepreneurs have been found to have a higher proportion of family members in their network (Greve and Salaff, 2003). There were 54 male and 56 female respondents in our sample. Male entrepreneurs were coded as 0 , and female entrepreneurs were coded as 1 .

Entrepreneur's age. Older individuals tend to have larger social networks (Renzulli et al., 2000). They also tend to have accumulated more social capital and financial resources, thereby reducing the need for external support in starting and growing a business (Parker, 2004). The ages of entrepreneurs in our sample ranged from 22 to 75 years and averaged 49 years.

Entrepreneur's education level. An owner's education level may impact the amount of knowledge and network support they may need and their overall entrepreneurship success (Diochon et al., 2008; Samuelsson and Davidsson, 2009). Respondents were asked to select their highest level of education completed from the following list:

(1) Less than high school ( $<1$ percent of respondents).

(2) High school/GED (9 percent).

(3) Some college (29 percent).

(4) Two-year college (14 percent).

(5) Four-year college (28 percent).

(6) Master's degree (15 percent).

(7) Doctoral degree (2 percent).

(8) Professional degree (JD, MD; 3 percent).

The mean response score was 4.3, with a range of 1 to 8 across the sample.

Company sales. Company sales and size can impact the types of relationships entrepreneurs form because smaller companies with few financial resources often deal with 
more uncertainty regarding resource requirements and sources. This circumstance, in turn, may influence the owner's personal contacts used to access these types of resources. We used a self-report measure of revenue for the most recent year; the mean revenue for our sample was $\$ 458,383$. A $\log _{10}$ transformation was used in the analysis (e.g. revenue of $\$ 458,383$ corresponds to a logarithmic measure of 5.66).

Company size. We measured company size by asking owners the number of full-time employees they employed in the most recent year. The mean company size in our sample was ten employees. Survey responses regarding company size were coded into one of the following three categories, which represented roughly equal-sized groups of responses:

(1) one full-time employee (just the owner);

(2) two to four full-time employees; and

(3) more than four full-time employees.

\section{Results}

Table IV lists descriptive statistics and correlations for each variable in the model. Because there were no very high correlations (i.e. $>0.7$ ) among the predictor variables, multicollinearity was not an issue.

Hierarchical multiple regression analysis was used to test the four hypotheses (see Tables V and VI). We used hierarchical regression because we wanted to test the differential impacts of the network variables between black and white entrepreneurs upon ESE, above and beyond control variables such as demographic variables regarding the entrepreneur and his or her business. A normal probability plot comparing the distribution of standardized residuals to a normal distribution was conducted to ensure the normal distribution of the data in our sample. The data were split based on the owner's ethnicity to allow testing of the hypotheses for each group. Table $\mathrm{V}$ shows the results for white entrepreneurs and Table VI shows the results for black entrepreneurs.

Model 1 represented the relationships among the control variables and our dependent variable ESE, whereas Model 2 represented the addition of the network ethnic diversity and ECC variables to Model 1.

For white entrepreneurs, business size was positively correlated with ESE, perhaps indicating that as entrepreneurial businesses grow in size, and coordination among labor and other resources becomes necessary, ESE plays a larger role. However, it

\begin{tabular}{|c|c|c|c|c|c|c|c|c|c|c|c|}
\hline Variables & Mean & $\mathrm{SD}$ & 1 & 2 & 3 & 4 & 5 & 6 & 7 & 8 & \\
\hline \multicolumn{12}{|l|}{ (1) Entrepreneur } \\
\hline (2) Entrepreneur age & 49.03 & 13.18 & -0.04 & & & & & & & & \\
\hline $\begin{array}{l}\text { (3) Entrepreneur } \\
\text { education }\end{array}$ & 4.25 & 1.47 & $-0.22 * *$ & 0.15 & & & & & & & \\
\hline $\begin{array}{l}\text { (4) Entrepreneur } \\
\text { ethnicity } \\
\text { (5) Company sales }\end{array}$ & 0.49 & 0.50 & 0.02 & $-0.40^{* * * * *}$ & -0.04 & & & & & & \\
\hline$\left(\log _{10}\right)$ & 4.78 & 1.26 & $-0.33^{* * * * *}$ & 0.04 & 0.14 & $-0.20 * *$ & & & & & \\
\hline $\begin{array}{l}\text { (6) Company size } \\
\text { (7) Emotional carrying }\end{array}$ & 1.99 & 0.80 & $-0.24^{* *}$ & $-0.18^{*}$ & 0.11 & -0.15 & $0.43 * * * *$ & & & & \\
\hline $\begin{array}{l}\text { capacity } \\
\text { (8) Network ethnic }\end{array}$ & 4.07 & 0.58 & $0.24 * *$ & -0.07 & -0.09 & -0.01 & 0.00 & $0.17^{*}$ & & & \\
\hline diversity & 0.24 & 0.25 & -0.09 & $-0.32 * *$ & 0.02 & $0.43 * * * *$ & -0.07 & $0.18^{*}$ & $-0.20 * *$ & & \\
\hline $\begin{array}{l}\text { (9) Entrepreneur } \\
\text { self-efficacy }\end{array}$ & 4.22 & 0.57 & 0.03 & $-0.24^{* *}$ & 0.00 & $0.19 * *$ & 0.12 & $0.26 * * *$ & $0.45^{* * * * *}$ & $0.26^{* * *}$ & $\begin{array}{r}\text { Table IV. } \\
\text { Descriptive statistics }\end{array}$ \\
\hline \multicolumn{12}{|c|}{ Notes: $n=110 . * p<0.1 ; * * p<0.05 ; * * * p<0.01 ; * * * * p<0.001$} \\
\hline
\end{tabular}

Case of black and white entrepreneurs 
NEJE

21,2

\begin{tabular}{lcc}
\hline Variables & Model 1 & Model 2 \\
\hline Constant $(y$ intercept) & $4.12^{* * * * *}$ & $2.16^{* * *}$ \\
Entrepreneur gender & 0.02 & 0.06 \\
Entrepreneur age & -0.16 & -0.02 \\
Entrepreneur education & -0.10 & -0.05 \\
Company sales $\left(\log _{10}\right)$ & -0.03 & 0.13 \\
Company size & $0.36^{* *}$ & 0.11 \\
Emotional carrying capacity & & $0.29^{* *}$ \\
Network ethnic diversity & 0.18 & $0.42^{* * *}$ \\
$R^{2}$ & 0.09 & 0.36 \\
Adjusted $R^{2}$ & 0.57 & 0.27 \\
SE & $2.14^{*}$ & 0.51 \\
$F$ & & $3.89^{* * *}$ \\
Significance of change in $F$ vs prior model & & $p<0.01$
\end{tabular}

Notes: $n=110$. Values represent standardized coefficients. ${ }^{*} p<0.1 ; * * p<0.05 ; * * * p<0.01 ; * * * * p<0.001$

Table V.

Standardized results of regression analysis to predict entrepreneurial self-efficacy of white entrepreneurs

Table VI.

Standardized results of regression analysis to predict entrepreneurial self-efficacy of Black entrepreneurs

\begin{tabular}{lcc}
\hline Variables & Model 1 & Model 2 \\
\hline Constant $(y$ intercept) & $3.79^{* * * * *}$ & $1.74^{* * * *}$ \\
Entrepreneur gender & 0.20 & -0.13 \\
Entrepreneur age & -0.14 & -0.14 \\
Entrepreneur education & 0.11 & 0.18 \\
Company sales (log 10$)$ & 0.28 & 0.20 \\
Company size & 0.09 & -0.06 \\
Emotional carrying capacity & & $0.70^{* * * *}$ \\
Network ethnic diversity & 0.13 & 0.16 \\
$R^{2}$ & 0.04 & 0.45 \\
Adjusted $R^{2}$ & 0.51 & 0.36 \\
Standard error & 1.48 & 0.41 \\
$F$ & & $5.31^{* * * * *}$ \\
Significance of change in $F$ vs prior model & & $p<0.001$ \\
Notes: $n=110$. Values represent standardized coefficients. $* p<0.1 ; * * p<0.05 ; * * * p<0.01 ; * * * * p<0.001$
\end{tabular}

is important to note that after all the network variables were added to the model, business size was no longer statistically significant, revealing the relative importance of network (i.e. contextual) variables over company demographics with regards to ESE.

The results of Model 2 supported H1a. There was a significant positive relationship between a white entrepreneur's ECC and ESE. H2a was also supported. There was a strong, positive relationship between a white entrepreneur's network ethnic diversity and ESE. The overall $R^{2}$ for Model 2 was 0.36 , which was statistically significant at $p<0.01$. The change in the $F$-statistic from Model 1 to Model 2 was also significant. Of the two network predictor variables, network ethnic diversity had the highest effect size with a standardized coefficient of 0.42 , which was statistically significant at $p<0.01$.

For black entrepreneurs, no control variables were statistically significant in Models 1 or 2 . The results of Model 2 support $H 1 b$. There was a strong, positive relationship between a black entrepreneur's ECC and ESE. However, $H 2 b$ was not supported. There was no significant relationship between a black entrepreneur's network ethnic diversity and ESE. The overall $R^{2}$ for Model 2 was 0.45 , which was statistically significant at $p<0.001$. The change in the $F$ statistic from Model 1 to Model 2 was also significant. 
In addition to the hypothesis testing results, we observed that black entrepreneurs had higher levels of ESE than white entrepreneurs $(M=4.11$ for white entrepreneurs and 4.35 for black entrepreneurs). This difference was significant $(F=5.07, p<0.05)$. We also found that black entrepreneurs had more ethnically diverse networks than white entrepreneurs ( $M=0.14$ for white entrepreneurs and 0.34 for black entrepreneurs). This difference was significant $(F=23.45, p<0.001)$.

\section{Discussion}

Our study results provide evidence that the ECC and the network ethnicity of a white entrepreneur's social network relationships are both positively related to his or her ESE. Importantly, when all of the network variables were entered into the model, owner and business demographic variables were no longer significant. We stress this result as it indicates the relative significance of contextual variables beyond company and entrepreneur demographics with regards to ESE. Further, both ECC and network ethnic diversity independently influence ESE for white entrepreneurs. Therefore, they are complementary, not substitutive, to the contribution of ESE.

For black entrepreneurs, we found evidence of ECC only - not network ethnic diversity - influencing ESE. As predicted, ECC was beneficial to the ESE of both white and black entrepreneurs but network ethnic diversity was only beneficial to the ESE of white entrepreneurs. At the same time, we found that black entrepreneurs' networks are more ethnically diverse than white entrepreneurs and this may be why they may not specifically benefit from network ethnic diversity. That is, because black entrepreneurs' networks, as compared to white entrepreneurs' networks, are already characterized by higher ethnic diversity, black entrepreneurs may not reap the additional benefits that white entrepreneurs do when they increase the ethnic diversity of their networks.

Entrepreneurship is a popular and important pursuit, yet many entrepreneurs fail. Improving ESE is a promising path, as the construct has been linked to various positive entrepreneurial outcomes. Our research had two primary aims. First, we wanted to test whether the ECC of relationships in entrepreneurial networks was positively related to ESE. We posited the positive ECC-ESE relationship because ECC provides both black and white entrepreneurs the opportunity to receive and process constructive criticism, obtain encouragement, and reflect on themselves and the social environment (e.g. helpful cues, benchmarking) in a positive emotional context.

Second, we hope that our research will encourage scholars to acknowledge that white entrepreneurs do benefit from connecting with black network actors, which can provide them with unique and valuable resources. At the same time, it is important to highlight the fact that black entrepreneurs had higher levels of ESE compared to white entrepreneurs and this may be a contributing factor to their recent entrepreneurial advancements.

Our research findings have important implications to the entrepreneur practitioner. Entrepreneurs need access not only to physical and financial resources but also to social relationships that provide an environment for learning, experimentation, and support. Unfortunately, most entrepreneurs build their personal networks from convenient ties such as close family and friends, a practice that often produces biases and redundancies. Our findings strongly suggest that entrepreneurs should build their networks strategically, looking for partners who can provide high-quality relationships through emotional support and diversity of perspective. The diversity aspect is especially crucial for white entrepreneurs. Additionally, entrepreneurship education programs should discuss ECC and network ethnic diversity when educating potential entrepreneurs about avenues to increase entrepreneurial success.

We can offer some recommendations for both black and white entrepreneurs regarding how to build networks strategically. The entrepreneur needs to perform continuous

Case of black and white entrepreneurs 
NEJE

21,2

116

self-evaluation and reflection on their network portfolio to ensure as few gaps and biases as possible. Network assessments can be made to measure the quality of connections and ethnic diversity. Coaches or mentors can offer personalized help in these areas. White entrepreneurs specifically need to make sure that they connect with diverse individuals given that these individuals can provide them with novel information.

One limitation of our research is that the cross-sectional design of our study precludes the ability to make causal inferences. The relationships that we found between ECC and ESE and network ethnic diversity and ESE could be reciprocal, meaning that our theorized independent variables could be dependent variables. For example, an entrepreneur with higher ESE may be more likely to have a social network characterized by relationships with higher ECC or higher network ethnic diversity. A future course of study would be to conduct longitudinal research to elucidate such possible causality. In addition, the cross-sectional nature of the study prohibits us from understanding how ESE, ECC, and network ethnic diversity have emerged over time. Given that we do not know the age of the businesses in the sample, it is possible that increases in ESE result from entrepreneurs' experience in the field rather than ECC or network ethnic diversity. Future research could use longitudinal approaches and consider business age to further examine the relationships discussed herein.

Future research could also expand on the conceptualization and operationalization of the entrepreneur's network. Ties among the entrepreneur's network contacts (i.e. alters) could be measured through survey questions answered by the entrepreneur. Such study would allow one to analyze the entrepreneur's network by means of critical network metrics such as density, cohesion, and fragmentation, and to study the role that the entrepreneur plays in the network, such as the broker role. This research would yield interesting analysis on the relationships between different start-up network structures and indicators of entrepreneurial success such as ESE.

Finally, our network ethnic diversity variable only addressed ethnicity and did not take into account that the experience of ethnicity may shift when ethnicity intersects with other demographic variables (e.g. gender, sexual orientation, and/or social class; Crenshaw, 1989). Future research might employ an intersectional research methodology allowing for more granular investigation of the interactive relationships between various demographic variables and entrepreneurial outcomes.

\section{Conclusion}

While ESE is not a panacea (Chen et al., 1998), we believe that our study provides encouraging news for entrepreneurs and entrepreneurship researchers. We hypothesized that ECC and network ethnic diversity improve the ESE of black and white entrepreneurs. Our findings suggest that black and white entrepreneurs may experience increased ESE if they proactively manage their networks to include relationships with high ECC. Further, white entrepreneurs' ESE may also be increased by increasing network ethnic diversity. In comparison, we believe that black entrepreneurs' ESE was not improved by network ethnic diversity given that their networks are already more ethnically diverse. The benefits of such ethnically diverse networks might have impacted other entrepreneurial outcomes such as their recent advancement in entrepreneurship.

\section{References}

Aldrich, H. (1989), "Networking among women entrepreneurs", in Hagan, O., Rivchun, C. and Sexton, D. (Eds), Women-Owned Businesses, Praeger, New York, NY, pp. 17-43.

Aldrich, H., Zimmer, C. and Jones, T. (1986), "Small business still speaks with the same voice: a replication of 'the voice of small business and the politics of survival'", The Sociological Review, Vol. 34 No. 2, pp. 335-356. 
Apfelbaum, E.P., Phillips, K.W. and Richeson, J.A. (2014), "Rethinking the baseline in diversity research: should we be explaining the effects of homogeneity?", Perspectives on Psychological Science, Vol. 9 No. 3, pp. 235-244.

Ardichvili, A., Cardozo, R. and Ray, S. (2003), "A theory of entrepreneurial opportunity identification and development", Journal of Business Venturing, Vol. 18 No. 1, pp. 105-123.

Bandura, A. (1977), "Self-efficacy: toward a unifying theory of behavioral change", Psychological Review, Vol. 84 No. 2, p. 191.

Bandura, A. (1997), Self-efficacy: The Exercise of Control, Freeman, New York, NY.

Bandura, A. (2006), "Guide for constructing self-efficacy scales", in Urdan, T. and Pajares, F. (Eds), Self-Efficacy Beliefs of Adolescents, Information Age Publishing, Greenwich, CT, pp. 307-337.

Baron, R.A., Byrne, D. and Branscombe, N.R. (2005), Social Psychology, 11th ed., Allyn and Bacon, Boston, MA.

Bates, T., Jackson, W.E. III and Johnson, J.H. Jr (2007), "Advancing research on minority entrepreneurship", The Annals of the American Academy of Political and Social Science, Vol. 613 No. 1, pp. 10-17.

Baum, J.A., Calabrese, T. and Silverman, B.S. (2000), “Don't go it alone: alliance network composition and startups' performance in Canadian biotechnology", Strategic Management Journal, Vol. 21 No. 3, pp. 267-294.

Baum, J.R. and Bird, B.J. (2010), "The successful intelligence of high-growth entrepreneurs: links to new venture growth”, Organization Science, Vol. 21 No. 2, pp. 397-412.

Baum, J.R. and Locke, E.A. (2004), "The relationship of entrepreneurial traits, skill, and motivation to subsequent venture growth", Journal of Applied Psychology, Vol. 89 No. 4, pp. 587-598.

Baum, J.R., Locke, E.A. and Smith, K.G. (2001), "A multidimensional model of venture growth", Academy of Management Journal, Vol. 44 No. 2, pp. 292-303.

Blanchflower, D., Levine, P. and Zimmerman, D. (1998), "Discrimination in the small business credit market”, National Bureau of Economic Research Working Paper No. 6840, New York, NY.

Blau, P.M. (1977), Inequality and Heterogeneity, Free Press, New York, NY.

Blau, R. and Alba, R.D. (1982), "Empowering nets of participation”, Administrative Science Quarterly, Vol. 27 No. 3, pp. 363-379.

Boyd, N.G. and Vozikis, G.S. (1994), "The influence of self-efficacy on the development of entrepreneurial intentions and actions", Entrepreneurship Theory and Practice, Vol. 18 No. 4, pp. 63-77.

Brass, D.J. (1984), "Being in the right place: a structural analysis of individual influence in an organization", Administrative Science Quarterly, Vol. 29 No. 4, pp. 518-539.

Brownlee, G. (2014), "Small business failure rates and causes", available at: www.isbdc.org/smallbusiness-failure-rates-causes/ (accessed June 7, 2016).

Brüderl, J. and Preisendörfer, P. (1998), "Network support and the success of newly founded business", Small Business Economics, Vol. 10 No. 3, pp. 213-225.

Bruyat, C. and Julien, P.-A. (2000), "Defining the field of research in entrepreneurship", Journal of Business Venturing, Vol. 16 No. 2, pp. 165-180.

Bullough, A., Renko, M. and Myatt, T. (2014), "Danger zone entrepreneurs: the importance of resilience and self-efficacy for entrepreneurial intentions", Entrepreneurship Theory and Practice, Vol. 38 No. 3, pp. 473-499.

Burt, R.S. (1982), Toward a Structural Theory of Action: Network Models of Social Structure, Perception, and Action, Academic Press, Inc., New York, NY.

Burt, R.S. (1995), Structural Holes: The Social Structure of Competition, Harvard University Press, Cambridge, MA.

Burt, R.S. (1998), “The gender of social capital”, Rationality and Society, Vol. 10 No. 1, pp. 5-46. 
Burt, R.S. (2004), "Structural holes and good ideas", American Journal of Sociology, Vol. 110 No. 2, pp. 349-399.

Carmeli, A., Brueller, D. and Dutton, J.E. (2009), "Learning behaviours in the workplace: the role of high-quality interpersonal relationships and psychological safety", Systems Research and Behavioral Science, Vol. 26 No. 1, pp. 81-98.

Cassar, G. and Friedman, H. (2009), "Does self-efficacy affect entrepreneurial investment?", Strategic Entrepreneurship Journal, Vol. 3 No. 3, pp. 241-260.

Chen, C.C., Greene, P.G. and Crick, A. (1998), "Does entrepreneurial self-efficacy distinguish entrepreneurs from managers?", Journal of Business Venturing, Vol. 13 No. 4, pp. 295-316.

Coleman, J. (1990), Foundations of Social Theory, Belknap Press, Cambridge, MA.

Cornwell, E.Y. and Cornwell, B. (2008), "Access to expertise as a form of social capital: an examination of race- and class-based disparities in network ties to experts", Sociological Perspectives, Vol. 51 No. 4, pp. 853-876.

Cox, L.W., Mueller, S.L. and Moss, S.E. (2002), "The impact of entrepreneurship education on entrepreneurial self-efficacy", International Journal of Entrepreneurship Education, Vol. 1 No. 2, pp. 229-245.

Crenshaw, K. (1989), "Demarginalizing the intersection of race and sex: a black feminist critique of antidiscrimination doctrine, feminist theory and antiracist politics", University of Chicago Legal Forum, Vol. 140, pp. 139-167.

Cummings, S. (1999), "African American entrepreneurship in the suburbs: protected markets and enclave business development", Journal of the American Planning Association, Vol. 65 No. 1, pp. 50-61.

Davidsson, P. and Honig, B. (2003), "The role of social and human capital among nascent entrepreneurs", Journal of Business Venturing, Vol. 18 No. 3, pp. 301-331.

DeNoble, A.F., Jung, D. and Ehrlich, S.B. (1999), "Entrepreneurial self-efficacy: the development of a measure and its relationship to entrepreneurial action", in Reynolds, W.D.B.R.D., Manigart, S., Mason, C.M., Meyer, G.D., Sapienza, H.J. and Shaver, K.G. (Eds), Frontiers of Entrepreneurship Research, P\&R Publications Inc., Waltham, MA, pp. 73-87.

Díaz García, M.C. and Carter, S. (2009), "Resource mobilization through business owners' networks: is gender an issue?", International Journal of Gender and Entrepreneurship, Vol. 1 No. 3, pp. 226-252.

Dimov, D. (2007), "Beyond the single-person, single-insight attribution in understanding entrepreneurial opportunities", Entrepreneurship Theory and Practice, Vol. 31 No. 5, pp. 713-731.

Dimov, D. (2010), "Nascent entrepreneurs and venture emergence: opportunity confidence, human capital, and early planning", Journal of Management Studies, Vol. 47 No. 6, pp. 1123-1153.

Diochon, M., Menzies, T.V. and Gasse, Y. (2008), "Exploring the nature and impact of gestation-specific human capital among nascent entrepreneurs", Journal of Developmental Entrepreneurship, Vol. 13 No. 2, pp. 151-165.

DuBois, W.E.B. (1903), The Souls of Black Folk, AC McClurg, Chicago, IL.

Duguid, M.M. and Goncalo, J.A. (2015), "Squeezed in the middle: the middle status trade creativity for focus", Journal of Personality and Social Psychology, Vol. 109 No. 4, pp. 589-603.

Dutton, J.E. and Heaphy, E.D. (2003), "The power of high-quality connections”, in Cameron, K., Dutton, J. and Quinn, R. (Eds), Positive Organizational Scholarship: Foundations of a New Discipline, BerrettKoehler, San Francisco, CA, pp. 263-278.

Edelman, L.F., Brush, C.G., Manolova, T.S. and Greene, P.G. (2010), "Start-up motivations and growth intentions of minority nascent entrepreneurs", Journal of Small Business Management, Vol. 48 No. 2, pp. 174-196.

Edmondson, A. (1999), "Psychological safety and learning behavior in work teams", Administrative Science Quarterly, Vol. 44 No. 2, pp. 350-383.

Fairlie, R.W. and Robb, A. (2007), "Families, human capital, and small business: evidence from the characteristics of business owners survey”, ILR Review, Vol. 60 No. 2, pp. 225-245. 
Fairlie, R.W. and Robb, A.M. (2008), Race and Entrepreneurial Success: Black-, Asian-, and WhiteOwned Businesses in the United States, Vol. 1, MIT Press Books, Cambridge, MA.

Falemo, B. (1989), “The firm's external persons: entrepreneurs or network actors?”, Entrepreneurship \& Regional Development, Vol. 1 No. 2, pp. 167-177.

Forbes, D.P. (2005), "The effects of strategic decision making on entrepreneurial self-efficacy", Entrepreneurship Theory and Practice, Vol. 29 No. 5, pp. 599-626.

Fulbright, K. (1985), "The myth of the double-advantage: black female managers", The Review of Black Political Economy, Vol. 14 Nos 2/3, pp. 33-45.

Gloria, A.M. and Hird, J.S. (1999), "Influences of ethnic and nonethnic variables on the career decision-making self-efficacy of college students", The Career Development Quarterly, Vol. 48 No. 2, pp. 157-174.

Granovetter, M. (1985), "Economic action and social structure: the problem of embeddedness", American Journal of Sociology, Vol. 91 No. 3, pp. 481-510.

Greve, A. and Salaff, J.W. (2003), "Social networks and entrepreneurship", Entrepreneurship Theory and Practice, Vol. 28 No. 1, pp. 1-22.

Hite, J.M. (2005), "Evolutionary processes and paths of relationally embedded network ties in emerging entrepreneurial firms", Entrepreneurship Theory and Practice, Vol. 21, pp. 113-144.

Hmieleski, K.M. and Baron, R.A. (2008), "When does entrepreneurial self-efficacy enhance versus reduce firm performance?”, Strategic Entrepreneurship Journal, Vol. 2 No. 1, pp. 57-72.

Hmieleski, K.M. and Corbett, A.C. (2008), "The contrasting interaction effects of improvisational behavior with entrepreneurial self-efficacy on new venture performance and entrepreneur work satisfaction", Journal of Business Venturing, Vol. 23 No. 4, pp. 482-496.

Hoang, H. and Antoncic, B. (2003), "Network-based research in entrepreneurship: a critical review", Journal of Business Venturing, Vol. 18 No. 2, pp. 165-187.

Honig, B. and Davidsson, P. (2000), "The role of social and human capital among nascent entrepreneurs", Academy of Management Proceedings, Vol. 2000 No. 1, pp. B1-B6.

Hopp, C. and Stephan, U. (2012), "The influence of socio-cultural environments on the performance of nascent entrepreneurs: community culture, motivation, self-efficacy and start-up success", Entrepreneurship \& Regional Development, Vol. 24 Nos 9/10, pp. 917-945.

Ibarra, H. (1995), "Race, opportunity, and diversity of social circles in managerial networks", Academy of Management Journal, Vol. 38 No. 3, pp. 673-703.

Jones, C., Hesterly, W.S. and Borgatti, S.P. (1997), “A general theory of network governance: exchange conditions and social mechanisms", Academy of Management Review, Vol. 22 No. 4, pp. 911-945.

Jones, C.M. and Seguin, P.J. (1997), "Transaction costs and price volatility: evidence from commission deregulation", The American Economic Review, Vol. 87 No. 4, pp. 728-737.

Kahn, W.A. (1990), "Psychological conditions of personal engagement and disengagement at work", Academy of Management Journal, Vol. 33 No. 4, pp. 692-724.

Kelley, D.J., Ali, A., Brush, C., Corbett, A.C., Daniels, C., Kim, P.H. and Rogoff, E.G. (2015), "Global Entrepreneurship Monitor: 2014 United States report", Global Entrepreneurship Research Association, London Business School, London, available at: www.babson.edu/Academics/centers/ blank-center/globalresearch/gem/Documents/GEM\%20USA,202014 (accessed June 7, 2016).

Kirschenbaum, D.S., Tomarken, A.J. and Humphrey, L.L. (1985), “Affect and adult self-regulation”, Journal of Personality and Social Psychology, Vol. 48 No. 2, pp. 509-523.

Kirzner, I.M. (2009), "The alert and creative entrepreneur: a clarification”, Small Business Economics, Vol. 32 No. 2, pp. 145-152.

Klyver, K. and Terjesen, S. (2007), "Entrepreneurial network composition: an analysis across venture development stage and gender", Women in Management Review, Vol. 22 No. 8, pp. 682-688.

Koellinger, P. and Minniti, M. (2006), "Not for lack of trying: American entrepreneurship in black and white", Small Business Economics, Vol. 27 No. 1, pp. 59-79.

Case of black and white entrepreneurs 
Krueger, N.F. (1993), "The impact of prior entrepreneurial exposure on perceptions of new venture feasibility and desirability", Entrepreneurship Theory and Practice, Vol. 18 No. 1, pp. 5-21.

Kwon, S.W. and Arenius, P. (2010), "Nations of entrepreneurs: a social capital perspective", Journal of Business Venturing, Vol. 25 No. 3, pp. 315-330.

Larson, A. (1992), "Network dyads in entrepreneurial settings: a study of the governance of exchange relationships", Administrative Science Quarterly, Vol. 37 No. 1, pp. 76-104.

Lawler, E.J. and Yoon, J. (1998), "Network structure and emotion in exchange relations", American Sociological Review, Vol. 63 No. 6, pp. 871-894.

Lee, S.Y., Florida, R. and Acs, Z. (2004), "Creativity and entrepreneurship: a regional analysis of new firm formation”, Regional Studies, Vol. 38 No. 8, pp. 879-891.

Lenth, R.V. (2006), "Java applets for power and sample size [computer software]", available at: www. stat.uiowa.edu/ rlenth/Power (accessed December 23, 2015).

Lorenzoni, G. and Lipparini, A. (1999), "The leveraging of interfirm relationships as a distinctive organizational capability: a longitudinal study", Strategic Management Journal, Vol. 20 No. 4, pp. 317-338.

McPherson, M., Smith-Lovin, L. and Cook, J.M. (2001), "Birds of a feather: homophily in social networks", Annual Review of Sociology, Vol. 21, pp. 415-444.

Markman, G., Balkin, D. and Baron, R. (2002), "Inventors and new venture formation: the effects of general self-efficacy and regretful thinking", Entrepreneurship Theory and Practice, Vol. 27 No. 2, pp. 149-166.

Markman, G.D. and Baron, R.A. (2003), "Person-entrepreneurship fit: why some people are more successful as entrepreneurs than others", Human Resource Management Review, Vol. 13 No. 2, pp. 281-301.

Markman, G.D., Phan, P.H., Balkin, D.B. and Gianiodis, P.T. (2005), "Entrepreneurship and universitybased technology transfer", Journal of Business Venturing, Vol. 20 No. 2, pp. 241-263.

Meek, W.R., Pacheco, D.F. and York, J.G. (2010), "The impact of social norms on entrepreneurial action: evidence from the environmental entrepreneurship context", Journal of Business Venturing, Vol. 25 No. 5, pp. 493-509.

Merolla, D.M. (2013), "The net black advantage in educational transitions: an education careers approach", American Educational Research Journal, Vol. 50 No. 5, pp. 895-924.

Meyer, B.D. (1990), "Why are there so few black entrepreneurs?”, No. w3537, National Bureau of Economic Research, New York, NY.

Muntean, S.C. and Ozkazanc-Pan, B. (2015), "A gender integrative conceptualization of entrepreneurship”, New England Journal of Entrepreneurship, Vol. 18 No. 1, pp. 27-40.

Murnieks, C.Y., Mosakowski, E. and Cardon, M.S. (2014), "Pathways of passion identity centrality, passion, and behavior among entrepreneurs", Journal of Management, Vol. 40 No. 6, pp. 1583-1606.

Murphy, P.J., Kickul, J., Barbosa, S.D. and Titus, L. (2007), "Expert capital and perceived legitimacy: female-run entrepreneurial venture signaling and performance", International Journal of Entrepreneurship and Innovation, Vol. 8 No. 2, pp. 127-138.

Ozgen, E. and Baron, R.A. (2007), "Social sources of information in opportunity recognition: effects of mentors, industry networks, and professional forums", Journal of Business Venturing, Vol. 22 No. 2, pp. 174-192.

Parker, S.C. (2004), The Economics of Self-Employment and Entrepreneurship, Cambridge University Press, Cambridge.

Preisendörfer, P., Bitz, A. and Bezuidenhout, F.J. (2012), "In search of black entrepreneurship: why is there a lack of entrepreneurial activity among the black population in South Africa?", Journal of Developmental Entrepreneurship, Vol. 17 No. 1, 18pp.

Puhakka, V. (2007), "Effects of opportunity discovery strategies of entrepreneurs on performance of new ventures", Journal of Entrepreneurship, Vol. 16 No. 1, pp. 19-51. 
Reagans, R. and Zuckerman, E.W. (2001), "Networks, diversity, and productivity: the social capital of corporate R\&D teams", Organization Science, Vol. 12 No. 4, pp. 502-517.

Renzulli, L.A. and Aldrich, H. (2005), "Who can you turn to? Tie activation within core business discussion networks", Social Forces, Vol. 84 No. 1, pp. 323-341.

Renzulli, L.A., Aldrich, H. and Moody, J. (2000), "Family matters: gender, networks, and entrepreneurial outcomes", Social Forces, Vol. 79 No. 2, pp. 523-546.

Robb, A.M. (2002), "Entrepreneurial performance by women and minorities: the case of new firms", Journal of Developmental Entrepreneurship, Vol. 7 No. 4, pp. 383-397.

Robinson, S. and Stubberud, H.A. (2010), "An analysis of informal social networks by industry", International Journal of Entrepreneurship, Vol. 14 No. 1, pp. 1-12.

Samuelsson, M. and Davidsson, P. (2009), "Does venture opportunity variation matter? Investigating systematic process differences between innovative and imitative new ventures", Small Business Economics, Vol. 33 No. 2, pp. 229-255.

Sarason, Y., Dean, T. and Dillard, J.F. (2006), "Entrepreneurship as the nexus of individual and opportunity: a structuration view", Journal of Business Venturing, Vol. 21 No. 3, pp. 286-305.

Settoon, R.P. and Mossholder, K.W. (2002), "Relationship quality and relationship context as antecedents of person- and task-focused interpersonal citizenship behavior", Journal of Applied Psychology, Vol. 87 No. 2, pp. 252-267.

Shalley, C.E. and Perry-Smith, J.E. (2008), "The emergence of team creative cognition: the role of diverse outside ties, sociocognitive network centrality, and team evolution", Strategic Entrepreneurship Journal, Vol. 2 No. 1, pp. 23-41.

Singh, R.P. (2000), Entrepreneurial Opportunity Recognition through Social Networks, Garland Publishing, New York, NY.

Singh, R.P., Knox, E.L. and Crump, M.E. (2008), "Opportunity recognition differences between black and white nascent entrepreneurs: a test of Bhave's model", Journal of Developmental Entrepreneurship, Vol. 13 No. 1, pp. 59-75.

Stephens, J.P., Heaphy, E.D., Carmeli, A., Spreitzer, G.M. and Dutton, J.E. (2013), "Relationship quality and virtuousness: emotional carrying capacity as a source of individual and team resilience", The Journal of Applied Behavioral Science, Vol. 49 No. 1, pp. 13-41.

Sutcliffe, K.M. and Vogus, T.J. (2003), "Organizing for resilience”, in Cameron, K., Dutton, J. and Quinn, R. (Eds), Positive Organizational Scholarship: Foundations of a New Discipline, Berrett-Koehler, San Francisco, CA, pp. 94-110.

Sweida, G.L. and Reichard, R.J. (2013), "Gender stereotyping effects on entrepreneurial self-efficacy and high-growth entrepreneurial intention”, Journal of Small Business and Enterprise Development, Vol. 20 No. 2, pp. 296-313.

Tams, S. (2007), "Constructing self-efficacy at work: a person-centered perspective”, Personnel Review, Vol. 37 No. 2, pp. 165-183.

Thomas, D.A. (1990), “The impact of race on managers' experiences of developmental relationships (mentoring and sponsorship): an intra-organizational study", Journal of Organizational Behavior, Vol. 2 No. 6, pp. 479-492.

Thomas., D.A. (1993), "The dynamics of managing racial diversity in developmental relationships", Administrative Science Quarterly, Vol. 38 No. 2, pp. 169-194.

US Small Business Administration (2012), "Do economic or industry factors affect business survival?", Small Business Administration, Washington, DC, available at: www.sba.gov/sites/default/files/ Business-Survival.pdf (accessed October 13, 2017).

Valdez, Z. (2011), New Entrepreneurs: How Race, Class, and Gender Shape American Enterprise, Stanford University Press, Palo Alto, CA.

Wasserman, S. and Faust, K. (1994), Social Network Analysis: Methods and Application, Cambridge University Press, New York, NY. 
Wenger, E. (2000), "Communities of practice and social learning systems”, Organization, Vol. 7 No. 2, pp. 225-246.

Wilson, F., Kickul, J. and Marlino, D. (2007), "Gender, entrepreneurial self-efficacy, and entrepreneurial career intentions: implications for entrepreneurship education”, Entrepreneurship Theory and Practice, Vol. 31 No. 3, pp. 387-406.

Yar Hamidi, D., Wennberg, K. and Berglund, H. (2008), “Creativity in entrepreneurship education”, Journal of Small Business and Enterprise Development, Vol. 15 No. 2, pp. 304-320.

Zhao, H., Seibert, S.E. and Hills, G.E. (2005), "The mediating role of self-efficacy in the development of entrepreneurial intentions", Journal of Applied Psychology, Vol. 90 No. 6, pp. 1265-1272.

Zimmer, C. and Aldrich, H. (1987), "Resource mobilization through ethnic networks: kinship and friendship ties of shopkeepers in England", Sociological Perspectives, Vol. 30 No. 4, pp. 422-445.

\section{Corresponding author}

Golshan Javadian can be contacted at: golshan.javadian@morgan.edu

For instructions on how to order reprints of this article, please visit our website: 